\title{
Perubahan Histologik Postmortem pada Kelenjar Brunner Hewan Coba
}

\author{
${ }^{1}$ Reza S. Sartika \\ ${ }^{2}$ Djon Wongkar \\ ${ }^{2}$ Sonny J. R. Kalangi
}

\author{
${ }^{1}$ Program Studi Pendidikan Dokter Fakultas Kedokteran Universitas Sam Ratulangi Manado \\ ${ }^{2}$ Bagian Anatomi-Histologi Fakultas Kedokteran Universitas Sam Ratulangi Manado \\ Email: rezasundarisartika96@gmail.com
}

\begin{abstract}
Studies of postmortem histological changes in digestive system showed a variety of changes related to postmortem time. This study was aimed to obtain the histological changes of Brunner gland within 24-hour interval using a domestic pig as model. This was a descriptive study. Samples of duodenum were taken at several time intervals, as follows: 0 hour, 1 hour, 2 hours, 3 hours, 4 hours, 5 hours, 6 hours, 7 hours, 8 hours, 9 hours, 10 hours, 12 hours, 14 hours, 16 hours, 18 hours, 20 hours, 22 hours, and 24 hours. The results showed that the earliest histological changes occurred at 3 hours postmortem which showed congestion, widened gland lumen, as well as hydrophic degeneration of gland cells. At 7 hours to 22 hours postmortem the changes became more visible and were associated with lysis of the gland cells. At 24 hours postmortem the lysis had covered $>50 \%$ of the gland cells, however, the Brunner glands could still be identified. Conclusion: The earliest changes occured at 3 hours postmortem in the forms of congestion, widened gland lumens, and hydrophic degeneration of gland cells which became more visible at 7-22 hour postmortem associated with gland cell lysis. The cell lysis covered most of the gland cells at 24 hours postmortem, however, the Brunner glands could still be identified.
\end{abstract}

Keywords: duodenum, autolysis, postmortem.

\begin{abstract}
Abstrak: Berbagai penelitian mengenai perubahan histologik postmortem dari organ sistem pencernaan telah dilakukan pada hewan coba yang memperlihatkan variasi perubahan histologik sehubungan dengan waktu postmortem. Penelitian ini bertujuan untuk mendapatkan gambaran perubahan histologik postmortem pada kelenjar Brunner hewan coba dengan interval waktu 24 jam. Jenis penelitian ialah deskriptif yang menggunakan babi domestik sebagai hewan coba. Interval waktu pengambilan sampel dari bagian duodenum ialah: 0 jam, 1 jam, 2 jam, 3 jam, 4 jam, 5 jam, 6 jam, 7 jam, 8 jam, 9 jam, 10 jam, 12 jam, 14 jam, 16 jam, 18 jam, 20 jam, 22 jam, dan 24 jam postmortem. Hasil penelitian mendapatkan bahwa perubahan awal terjadi pada 3 jam postmortem yang menunjukkan kongesti dan lumen kelenjar melebar, serta degenerasi hidropik pada sel-sel kelenjar Brunner. Perubahan semakin tampak pada 7 jam sampai 22 jam postmortem, dan mulai terjadi lisis sel-sel kelenjar Brunner. Pada 24 jam postmortem lisis yang terjadi telah mencapai sekitar 50\% sel kelenjar tetapi kelenjar Brunner masih dapat diidentifikasi. Simpulan: Perubahan awal terjadi pada 3 jam postmortem yang menunjukkan kongesti dan lumen kelenjar melebar serta degenerasi hidropik pada sel-sel kelenjar Brunner yang terus berlangsung disertai lisis sel-sel kelenjar yang pada 24 jam postmortem telah mencapai sebagian besar sel kelenjar tetapi kelenjar Brunner masih dapat diidentifikasi.
\end{abstract}

Kata kunci: duodenum, autolisis, postmortem

Kematian (mortem) adalah suatu keadaan dimana fungsi vital tubuh berhenti secara permanen yang dapat dikenal secara klinis pada seseorang berupa tanda kematian. ${ }^{1}$ 
Duodenum ialah segmen terpendek usus halus, ${ }^{2}$ berukuran panjang $20-30 \mathrm{~cm}^{3}$ Ciri khas duodenum ialah adanya kelenjar duodena tubuloasinar (kelenjar Brunner) yang bercabang-cabang di submukosa. Duktus ekskretoriusnya menembus muskularis mukosa untuk mencurahkan sekresinya di dasar kelenjar intestinal (kriptus Lieberkuhn). Vili duodenum berbentuk seperti daun. Struktur yang juga terlihat pada duodenum yaitu plika sirkularis berupa lipatan-lipatan mukosa yang sangat khas pada duodenum dan jejunum. ${ }^{4}$

Penelitian-penelitian postmortem melaporkan adanya variasi perubahan histologik sehu-bungan dengan waktu postmortem pada berbagai organ sistem pencernaan. ${ }^{5-10}$ Penelitian ini bertujuan untuk mendapatkan perubahan histologik postmortem pada kelenjar Brunner hewan coba mengingat letak duodenum antara gaster dan ileum. Penelitian ini menggunakan babi domestik sebagai hewan coba karena pola dekomposisinya menyerupai manusia. ${ }^{11}$

\section{METODE PENELITIAN}

Jenis penelitian ini ialah deskriptif. Penelitian dilakukan di Laboratorium Anatomi-Histologi Fakultas Kedokteran Universitas Sam Ratulangi Manado dan Pusat Diagnostik Patologi Anatomi Manado yang dilaksanakan pada tanggal 20-21 Oktober 2017. Hewan coba yang digunakan ialah babi domestik dengan berat $20 \mathrm{~kg}$ dan

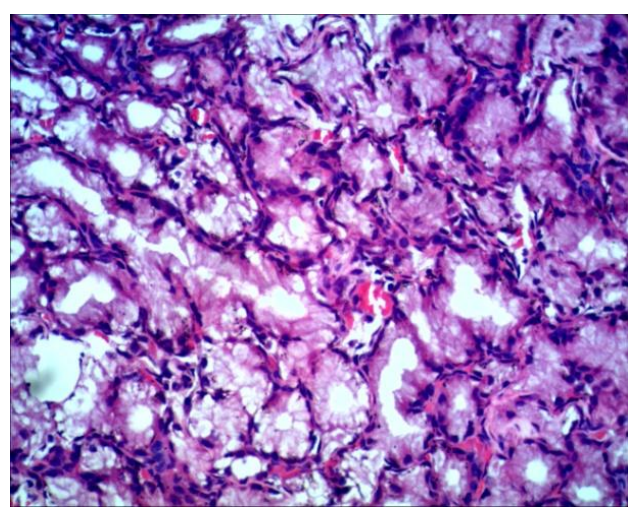

Gambar 1. Pada 0 jam postmortem kelenjar Brunner tampak normal (pembesaran 400x) secara fisik tidak ada luka, sehat, dan aktif.

Hewan coba dimatikan dengan tusukan pada jantung. Setelah hewan coba henti napas, waktu kematian dicatat. Pengambilan sampel dilakukan dengan interval waktu: 0 jam, 1 jam, 2 jam, 3 jam, 4 jam, 5 jam, 6 jam, 7 jam, 8 jam, 9 jam, 10 jam, 12 jam, 14 jam, 16 jam, 18 jam, 20 jam, 22 jam, dan 24 jam postmortem. Sampel difiksasi dengan formalin 10\% kemudian diproses di Pusat Diagnostik Patologi Anatomi. Pengamatan preparat dan pembuatan mikrofoto dilakukan menggunakan mikroskop cahaya Olympus CX21FS1 dengan pembesaran 40x, 100x, dan 400x, serta Optilab viewer.

\section{HASIL PENELITIAN}

Gambaran histologik pada 0 jam sampai 1 jam postmortem menunjukkan kelenjar Brunner masih tampak normal (Gambar 1, Tabel 1). Perubahan awal terjadi pada 3 jam postmortem yang menunjukkan gambaran kongesti dan lumen kelenjar tampak melebar, serta degenerasi hidropik pada sel-sel kelenjar Brunner (Gambar 2, Tabel 1). Perubahan semakin bertambah pada 7 22 jam postmortem dan mulai terlihat lisis sel-sel kelenjar Brunner (Gambar 3-5, Tabel 1). Pada 24 jam postmortem lisis yang terjadi mencapai sekitar $50 \%$ tetapi kelenjar Brunner masih dapat diidentifikasi (Gambar 6, Tabel 1).

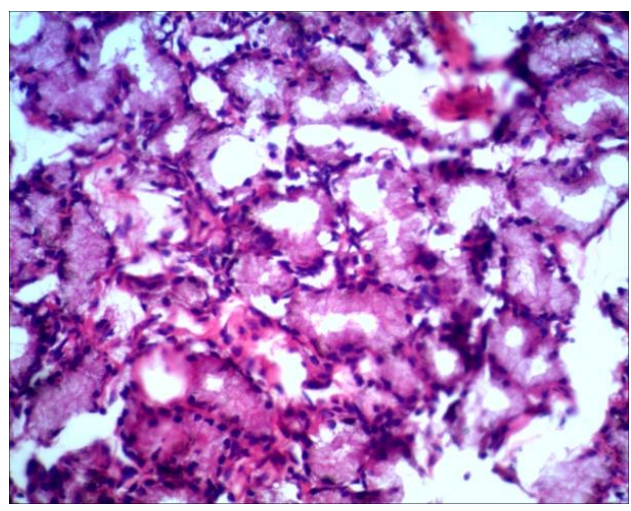

Gambar 2. Pada 3 jam postmortem tampak kongesti, lumen kelenjar melebar dan degenerasi hidropik sel-sel kelenjar Brunner (pembesaran 400x) 


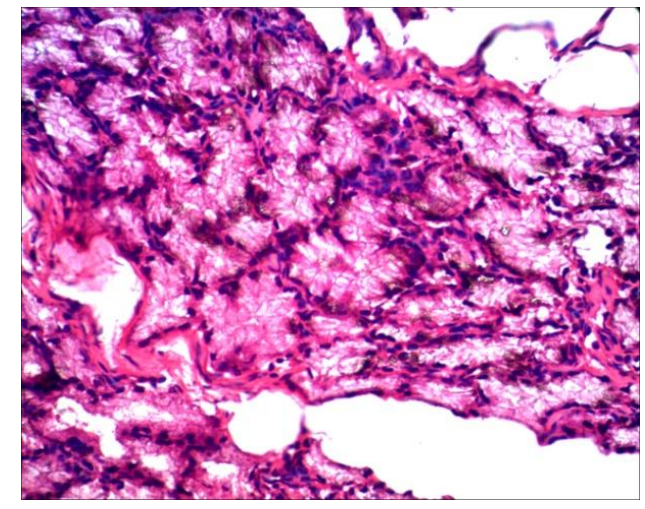

Gambar 3. Pada 7 jam postmortem tampak kongesti, lumen kelenjar melebar, degenerasi hidropik sel-sel kelenjar Brunner, dan lisis pada sebagian kecil sel-sel kelenjar Brunner (pembesaran 400x)

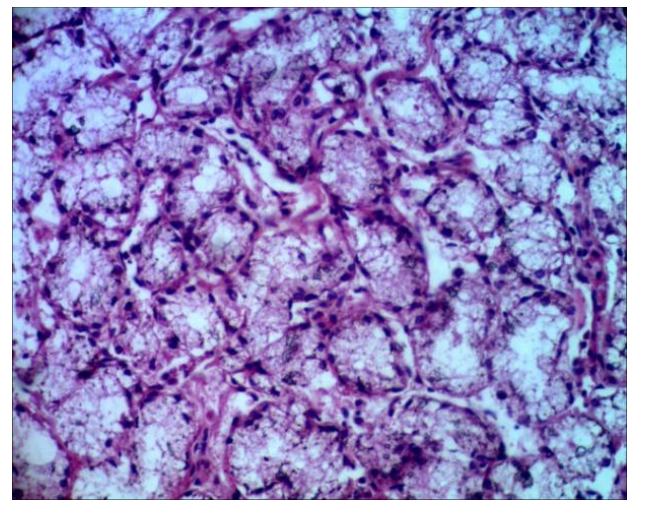

Gambar 5. Pada 22 jam postmortem tampak kongesti, lumen kelenjar melebar, degenerasi hidropik sel-sel kelenjar Brunner dan lisis sel-sel kelenjar Brunner bertambah (pembesaran 400x)

\section{BAHASAN}

Pada makhluk hidup yang mengalami kematian maka akan terjadi proses autolisis, yaitu pelunakan dan pencairan jaringan yang terjadi dalam keadaan steril dan timbul akibat kerja enzim-enzim digestif yang dilepaskan oleh sel-sel postmortem dan hanya dapat dicegah dengan pembekuan jaringan. ${ }^{12}$ Tingginya insidensi dari autolisis yang terjadi dalam waktu singkat pada usus halus membuatnya kurang dapat diandalkan dalam pemeriksaan postmortem apabila waktu setelah kematian telah berlangsung cukup lama. ${ }^{5}$

Salah satu perbedaan antara usus halus dan saluran cerna lain seperti esofagus, gaster, dan kolon yaitu organ-organ terse-

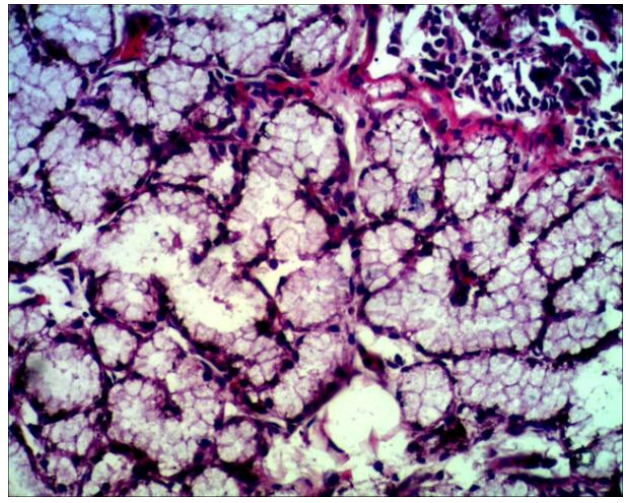

Gambar 4. Pada 14 jam postmortem tampak kongesti, lumen kelenjar melebar, degenerasi hidropik sel-sel kelenjar Brunner, dan lisis pada sebagian kecil sel-sel kelenjar Brunner. (pembesaran 400x)

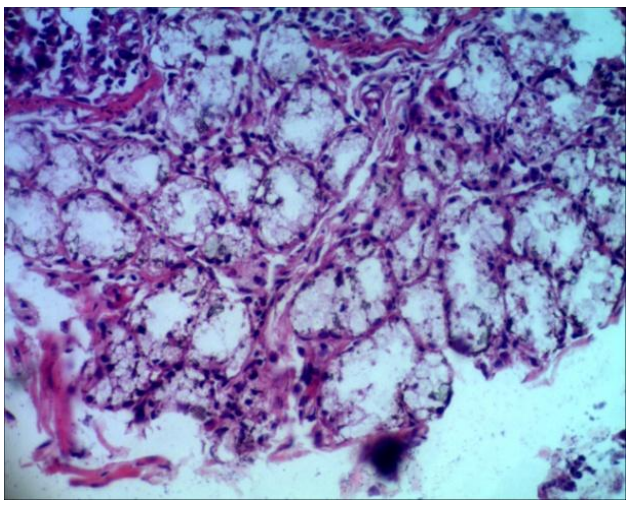

Gambar 6. Pada 24 jam postmortem kongesti, lumen kelenjar melebar dan degenerasi hidropik sel-sel kelenjar Brunner masih tampak. Lisis pada sel-sel kelenjar Brunner bertambah dan mencapai $>50 \%$ sel-sel kelenjar (pembesaran 400x)

but hanya menunjukkan sedikit perubahan pada beberapa jam pertama postmortem sedangkan vili usus halus sangat rentan terhadap proses autolisis. ${ }^{6}$

Hasil penelitian ini pada 0 jam sampai 1 jam postmortem menunjukkan kelenjar Brunner masih tampak normal. Hal ini tidak selaras dengan penelitian Theodore et al. ${ }^{7}$ yang melaporkan bahwa perubahan histologik usus halus ileum babi mulai teridentifikasi pada 0 jam postmortem berupa kongesti kelenjar intestinal.

Perubahan awal terjadi pada 3 jam postmortem menunjukkan lumen kelenjar melebar, tampak kongesti, dan juga tejadi degenerasi hidropik pada sel-sel kelenjar Brunner. Hal ini tidak sejalan dengan hasil 
Tabel 1. Perubahan mikroskopik kelenjar Brunner yang dihubungkan dengan waktu postmortem

\begin{tabular}{ccccc}
\hline $\begin{array}{c}\text { Waktu postmortem } \\
\text { (jam) }\end{array}$ & \multicolumn{2}{c}{ Perubahan mikroskopik } & \\
& Kelenjar Brunner & Kongesti & $\begin{array}{c}\text { Degenerasi } \\
\text { hidropik }\end{array}$ & Lisis \\
\hline 0 & Normal & $+/-$ & $+/-$ & - \\
1 & Normal & + & +- & - \\
2 & Lumen mulai tampak melebar & + & + & - \\
3 & Lumen tampak melebar & + & + & - \\
4 & Lumen tampak melebar & + & + & - \\
5 & Lumen tampak melebar & + & + & - \\
6 & Lumen tampak melebar & + & + & $+/-$ \\
7 & Lumen tampak melebar & + & + & $+/-$ \\
8 & Lumen tampak melebar & + & + & $+/-$ \\
9 & Lumen tampak melebar & + & + & $+/-$ \\
10 & Lumen tampak melebar & + & + & $+/-$ \\
12 & Lumen tampak melebar & + & + & $+/-$ \\
14 & Lumen tampak melebar & + & + & $+/-*$ \\
16 & Lumen tampak melebar & + & + & $+/-*$ \\
18 & Lumen tampak melebar & + & + & $+/-*$ \\
20 & Lumen tampak melebar & + & + & $+/-*$ \\
22 & Lumen tampak melebar & + & $+/-$ & $+/-*$ \\
\hline
\end{tabular}

Ket: + Terindentifikasi; - Tidak teridentifikasi; +/- Sebagian kecil; +/-* Bertambah

penelitian Lilingan et al. ${ }^{8}$ yang memperlihatkan bahwa perubahan histologik gaster babi mulai teridentifikasi pada 2 jam postmortem sebagai kongesti kelenjar fundus.

Penelitian serupa yang menggunakan hewan coba babi juga dilakukan oleh Lapian et al. ${ }^{9}$ yang mendapatkan perubahan mikroskopik postmortem paling awal pada usus besar terjadi pada 2 jam postmortem berupa kongesti dengan lumen kripta Lieberkuhn yang melebar. Goni et al. ${ }^{10}$ menyatakan perubahan mikroskopik pankreas dimulai pada 2 jam postmortem berupa kongesti asini pankreas.

Perubahan semakin tampak pada 7-22 jam postmortem dimana lumen tampak melebar, kongesti, degenerasi hi-dropik selsel kelenjar Brunner, dan mulai terjadi lisis pada sebagian sel-sel kelenjar. Pada 24 jam postmortem lisis yang terjadi telah mencapai sekitar 50\% sel-sel kelenjar tetapi kelenjar Brunner masih dapat diidentifikasi. Hal ini tidak selaras dengan hasil penelitian Rahmadana et al. ${ }^{13}$ pada organ ginjal yang memperlihatkan terjad-inya nekrosis tubuli distal 12 jam post-mortem dan nekrosis pada hampir seluruh struktur-struktur tersebut pada 24 jam postmortem.
Berdasarkan hasil-hasil penelitian di atas dapat disimpulkan bahwa terdapat perbedaan waktu terjadinya perubahan mikroskopik postmortem. Perbedaan hasil penelitian ini mungkin dapat disebabkan oleh kandungan sel-sel organ yang memiliki banyak enzim yang diasumsikan dapat memengaruhi terjadinya perubahan struktur sel dan selanjutnya lisis sel. Demikian pula metode penelitian yang digunakan termasuk suhu lingkungan, cara penilaian, teknik pengamatan, maupun kualitas preparat yang digunakan; kesemuanya dapat menghasilkan perbedaan dalam pengamatan.

\section{SARAN}

Diperlukan penelitian lebih lanjut dengan menggunakan jumlah sampel yang lebih besar dengan interval waktu lebih rinci. Selain itu dianjurkan untuk menggunakan pengecatan khusus untuk kelenjar Brunner sehingga perubahan morfologik sel dapat diamati dengan lebih jelas

\section{DAFTAR PUSTAKA}

1. Death. Kamus Kedokteran Dorland (31st ed). Jakarta: EGC, 2010; p. 556.

2. Eroschenko VP. Atlas Histologi diFiore: 
Sartika, Wongkar, Kalangi: Perubahan histologik postmortem pada kelenjar Brunner ...

dengan Korelasi Fungsional (11th ed). Jakarta: EGC, 2008; p. 304-7.

3. Paulsen F, Waschke J. Sobotta Atlas Anatomi Manusia: Organ-Organ Dalam (23rd ed). Jakarta: EGC, 2010; p. 86-90.

4. Junqueira LC, Carneiro J. Histologi Dasar Teks \& Atlas (10th ed). Jakarta: EGC, 2007; p. 395-404.

5. Herbert JK. Morphologic considerations in the interpretation of gastrointestinal disorders. Toxicol Pathol. 1988;16(2): 110-7.

6. Loehry CA. Creamer B. Post-mortem study of small intestinal mucosa. BMJ. 1966; 1:827-9.

7. Theodore VJ, Wangko S, Kalangi S. Gambaran histologik usus halus pada hewan coba selama 24 jam postmortem. eBm. 2017;5(1).

8. Lilingan M, Kalangi S, Wangko S. Gambaran histologik gaster pada hewan coba selama 24 jam postmortem. eBm.
2016;4(1).

9. Lapian C, Wangko S, Wongkar D. Gambaran histologik usus besar pada hewan coba postmortem. eBm. 2016;4(2).

10. Goni L, Wongkar D, Ticoalu S. Gambaran makroskopik dan mikroskopik pankreas pada hewan coba postmortem. eBm. 2017;5(1).

11. Swindle MM, Makin A, Herron AJ, Clubb FJ Jr, Frazier KS. Swine as models in biomedical research and toxicology testing. Vet Pathol. 2012; 49(2):344-56.

12. Budiyanto A, Widiatmaka W, Sudiono S, Mun'im TWA, Hertian S, Sampurna B, et al. Ilmu Kedokteran Forensik (1st ed). Cetakan Ke-2. Jakarta: Bagian Kedokteran Forensik FKUI, 1997; p. 26-33.

13. Rahmadana B, Wangko S, Kalangi S. Gambaran histologik ginjal hewan coba postmortem. eBm. 2014;2(2). 